\section{業 界 情 勢}

\section{化學工菜藥品統制會社改組臨的總會 日本化學}

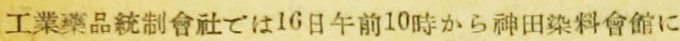
扣いて軍需省係官，化學工業統制會石川會長臨席，統制

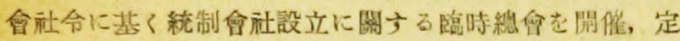

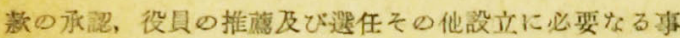

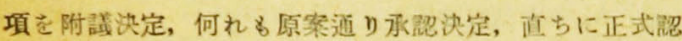

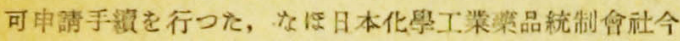
回の改組設立を契临に化學工業統制會の會几として加入 するとととなつてきり，近く常局より破令されるはずて ある, 同日決定せる社長, 理事, 監事及び相談役, 䄆問, 參興次○如乙

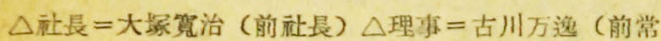
纾) 三田秀太耶 (同) 藤井學 (同) 品川幾 (同) 長岛

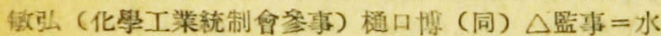

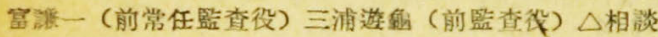

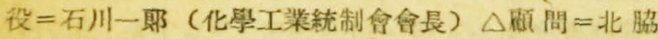

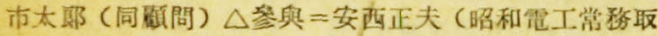

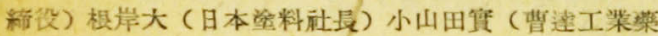
品畞給社脣) 佐野孝丸 (堺化學工業取締役) 田中音吉

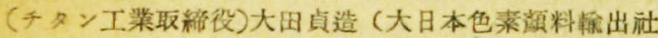

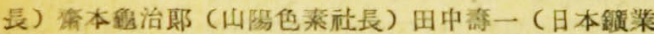

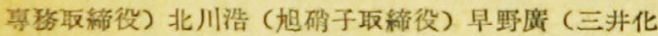

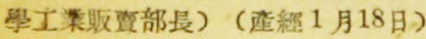

化工統・賦課金徽收率を改正 化學工業統制會 は第 2 次統制品目の迫加を乫機として各般の事務刷新を 考虑してるるが，先づ會且に對する賦踝金の徽收率さ改

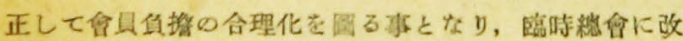
正案を撨出する事となつた，從來の微收率は平均して千

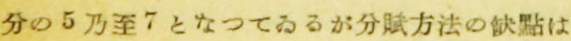

1. 劃一的に流れて一般に新製品に對して负譄が過大を 名る場合加ある

2. 現行分賦金は工坦渡值段に對して賦棵してるるため 包装䨘等を合委如場合があるが，之らは不合理である 等であるか㴗するに現行胜課金制度は化學統制會創立の

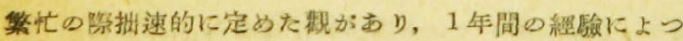
て各製品の特殊事情は略々明かとなつたので統制會では 之を合理化して會具贫擔の公平化を國らんとするすの

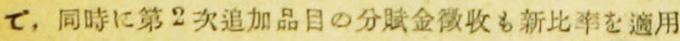
うる筈である。(日荤經1月17日)

有機合成品統制社社長に吉川氏 存機合成品統制

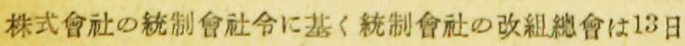

午後 2 時から東京富澤町同社會議室で開催, 定款その他

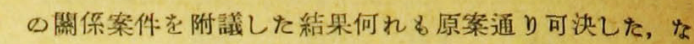
ほ新役員には社長に化學工業統制會理事吉川買氏が推蔗 され理事秥よび監事は次の如く選任をみた

㖣長吉川面 (化學工業統制會理事) 理事志村丑三 (鹤 配給會社常務) 三好舜平 (同業務部艮) 織田研一(統 制會理事) 三自文治 (同カーバイト部退) 監事宮原敏 (需氣化學監查役) 吉田信一(元商工技陑)

（童經1月14日）

\section{有機合成配給會社続組改組準備 有機合成品配給} 統制會社は，炤和18年 4 月に㓱立して，さきの溶到共㤆 會社の業䅂を繼承しブタノール，アセトン,メタノール， 醌酸などの時局下最尖端を行く新舆化學工業品の一元的 配給統制を宽施し來つたが、これら各裂品の統制は一段 そ强化する絕對必要性が高まつて來たので,軍需省ては, 同會社に對し統制會社命第 3 焂の第 2 俱による統制會於 の設立命命を發した、よつてとの命令に接した同社ては

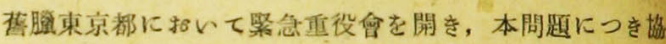
議を開いた結果，少くとも本月中にてれを完了するとと になってるるので，早速新統制畣社定款の作留に着手し 來る14日同站東京本社に臨時總會を招集して, 統制會站 命に上る新會社㓣立と、これに移行の件を附㦈うるとを に決定した（泼細1月4日）

\section{新コム製品材料會社設立準備進捗 ゴム製品材} 料會社の强化と生, 再生ゴム配給一元化につんては茠胴 當局上り當事者爪噛し中洨しがあり目下ゴム統制會を中 心に研究中であるが，大體新材料合社は 3 月 1 日より新

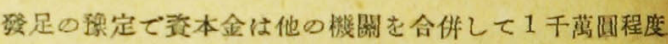

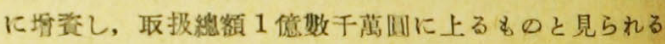
佾ゴム裂品原料たる有棧ゴム促道劑，カーボンブラック 等は現在原材料會垬の学握外にあるが之の急速な解決が 要望されてるる(日这絕 1 月18日)

コム工業界凟本合同磯運高潮 全國工場各單位别

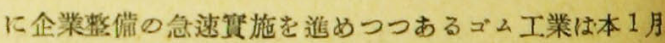
中をるつて企業整借されるとととなうたがさらに勞務括

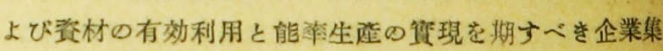
中方策に關しゴム統制會はその甚礎案作成に着手, ゴム

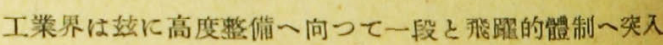
するに至つた，乙かして企業集中心能犁的方策は資本合

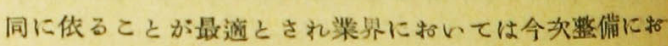

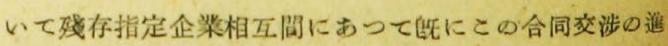
捗をみてるるるの及び急速に交涉の成立をみをるの等が あり今や企業集中合理化の機禹は最高潮き呈するに至り 路越が法目される。 
即らゴム工業における企業整備は業種の多岐性と の蕧雜性とにより 今次整備の指導方法が先づ運轉庭止の 各工場指定數を餘㭲のあるところ一落付け爾後残存企業 間の企業的通曉性によつて更に高次の整備を決行すると んふ二段構へになつてるるので業界にょける幊本合同機

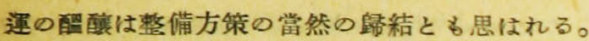

かくて同一業種及び近似業種間の䁈本合同は本 1 月の 整備期限をまたず自發的進展に移り $2-3$ 月頃には加速 度的に旋回するすのと見られる、ゴム統制會の企業集中

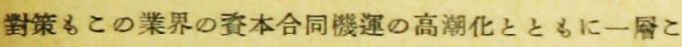
れを合理的に拍車づけるるのとされてるる。

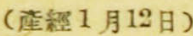

\section{染料工業企業整備に强力中核體を設置 染料工}

業の企業整備は, 內容吕複㒕なるのと業者會社汃相常多

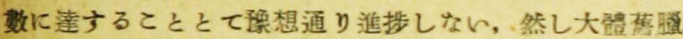
末に目斯がつきての分にて進めば本る3 月中には大错整 借は完了する見边であつて後は共助金問題に入るととに 切。

右整備の對象となる業者は染料工䋇系（中間物製造業

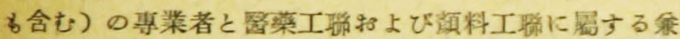

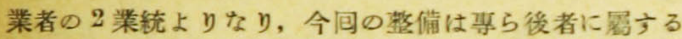
釡業者の大部分が整储要絧に基き庭止さるに至つたがそ

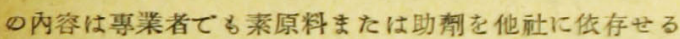
るの或は中間物のみを笠造せる中間工業者と, さらに盆

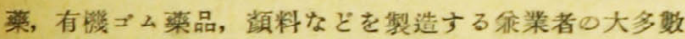
が通用され庣止工場の指命が發せられ，殘存工業江結局 專業の數社に原縮され，染料工業に對する整借が種々の 面より見て相當强硬であつたととが窺知される。

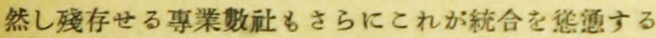
がその方針はその內最す有力にて製造上原料その他につ

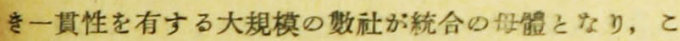
の母體はを整備後の染料工業の强力中核體となつて指 筫的立場飞置かれるるのである，此結果中校照の指令を 受りた日本染料は尾崎化學を，た三井化學は精萑化學 を合併すへく交涉を進めて居るから近く成立調印を見る 模漛てある，從つて整備後の染料工業は特異の性格を有 する中核體たる大規模の生產會社に上り全企業者にたい

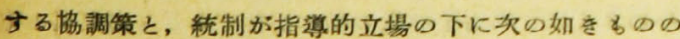
賽行方が要請されてるるゃらである

(1) 各製造業者の首䐉の連繫の强化協調策 ( 2 ）生産 分野の統一 ( 3 ) 生座の協定問题 (4) 技街の相互公 闒 (5) 各業者の設備の利用策の推進

(在經 1 月 14 日)

\section{笲 染料及びタール系中間物・資産評價基準決る}

(農商省發表) 農商省では染料及でタール系中間物工業

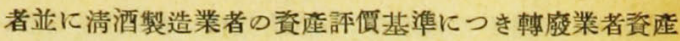
評價中央委員會に諮問中のところ同委員會では鹤臘27日 化學部會及び食品部會に於いて答申案を決定答申した， よつて同省では 8 日附各地方長官宛通㣰き發した，其大 要は左の如くである

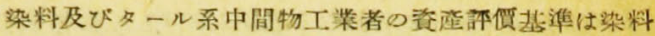

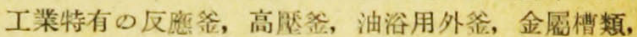

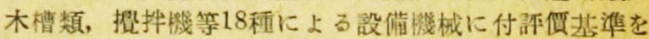

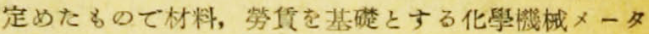
一の現賽の契作侸格に其を何過去に於いて設定された

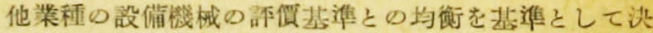
定したすのである(日在經1月10日)

\section{タール系炭煤の質的向上へ 日本カーボン・ブラ} ック統制会社ではタール系カーボン・ブラックが量的及 び筫的に重要な使命を有してるる點に鑑み，現在行はれ つつあるタール系カーボン・ブラック生在方法の技衡的 改善に上る

1. 裴品收学の向上

1. 徽粒子製品の生產

1. 水溶性カーボン・ブラックの生產

等の形究を行ひ，確乎たるタール系カーボン・ブラック

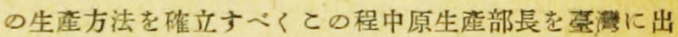
張せしめ總督府天然ガス研究所及び帝石工場に於いて䓅 衍的研究に從事せしめる事になつた，即占現在のカーポ ン・フララック生產管强の重點は原料事情及び製品の資的 確保の見地加らしてタール系カーポン・ブラックに浨せ られてるるが，現在の生産方法に就いては未だ改善を必 要とする點が殘されてるるので，帝石チャンネル法の生

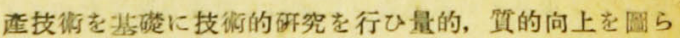
んとするるのである

特に水沿性カーポン・フラックはゴム配合に際して極 めて重要な問題であるが、タール製品を原料とするカ ーボンブラックにはての水溶性がきため, 製品の第 二炏的處理に上り水溶性のカーボン・フラックとしア ム配合に好結果を與一んとするるのである

(日蓙縃1月26日)

\section{化學统制會二部曼決る 化學工業統制會では第 2} 次追加品目に對する統制業弨の開始を急いでるるが，先

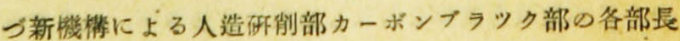

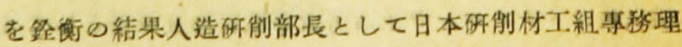
事秋山惐维，カーポンブラック部長にカーポンブラック 統制命社常袺高橋㨁道の兩氏が定した

(日厘經 1 月2 3 日) 
硫酸生産制度强化 化學工業統制畣ではてのほど大 岅支部管內に和け石硫酸製造業者を新大阪ホテルに參集 を求め, 硫酸生產指示量の强化方策につき愁談會を開い ‡, この日統制合上り白柤硫酸部長, 陸田同生产課長, 桝村大阪支部主任之の他, 日本硫酸上り山本理事小林支 店長その他, 生库業者上り住友化學, 日空化學工業, 日 本簧業, 铜生童業, 神島化學工業, 帝國化工その他出席

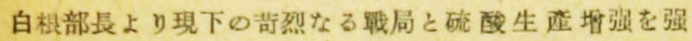

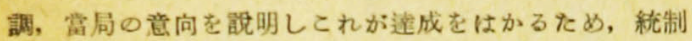

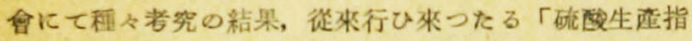
示量」をして一段と强化うるととに决定した

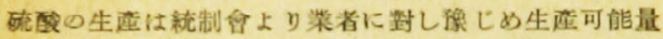

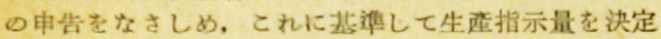

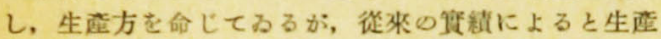

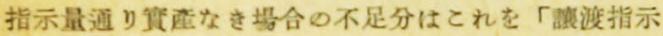

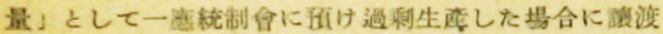
指示最と差引する仕租となつてをり

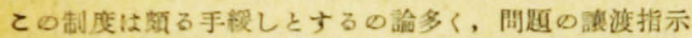
量制度は一然中止して, 統制合上り示遠したる生座指示

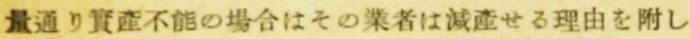
て冝接㷅需者に申請し諒解を求むることに改訂, との新 制度江第 4 - 4 牛期の 1 月分に进及筫施する旨を中湾さ

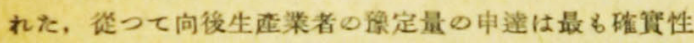

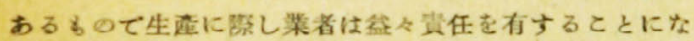

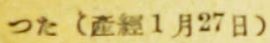

\section{アンモニア緊急增座・化翼統推進機厥設置 平}

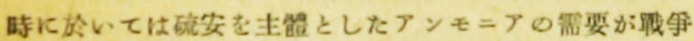

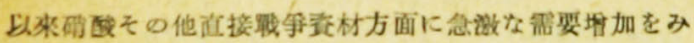

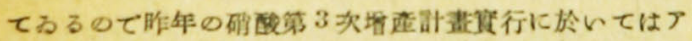

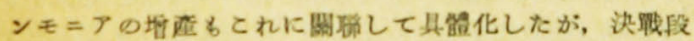
有下フンモニアの供給碳保は極めて承要となつたので

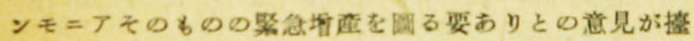
酘してるる

從來の考一て行けばアンモニア生就は直ちに硫安生産 を意拣してれは䬦ら化學肥料となつたるのであるが，大

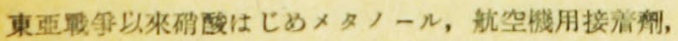

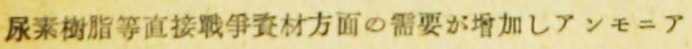
の供給琟保如何は極めて重要な問遁となるに至つてる

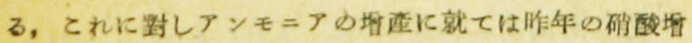

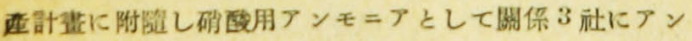
モニア製造没備控张を行はしめたのてあるが，い主ゅ确

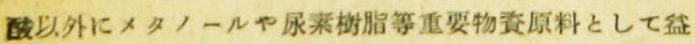
そその霹要が激坦しつつあるのてての際硫安を主能とし

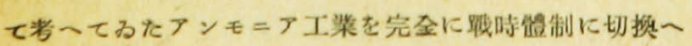
硫安, 㗂酸等, メタノール等一聯のアンモ
業品を確保する如くアンモニアそのるのの㙁座に對し集 中的策施を讙じその緊急坦座を圆る必要があるといふの である

これに對しアンモニアの配給統制については昨秋化業 工業統制合て筫施したが，更に同統制會でるその必要を 痛感し, アンモ $=$ ア坦座に關する推進機關設置の計畫を ある模棬で近く何等かの形でその貿現をみるるのと期待 されてるる(日繶1月25日)

石炭酸そ緊念增産・各社對策を攻究 合板製造の

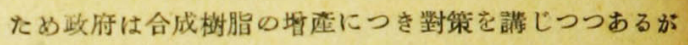
先つ主原料てる石炭酸の垁厘が必要であり, 關係留社て

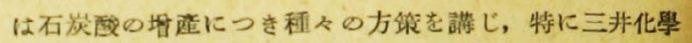
の新方式による石炭酸堦正が注目されてるる

三井化學ではラシッヒ法の石炭酸製造を研究して近く

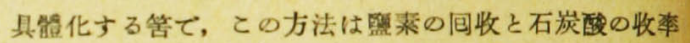
が高いといふ大をな特徽ががありその成功が期待されて

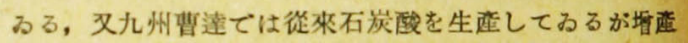
計畫を具體化せんとしてるる

合成樹脂の㒄在は石炭酸又はその同族體 (クレゾール 等) とその相手となるホルマリンとが例行的に㙁库され ねばならない゚て，目下ホルマリンに比し生差が稍低い

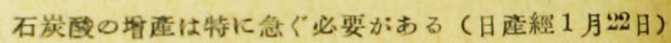

合成樹脂增産に曙光 航空譏坦產の目下合成椭脂。

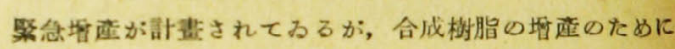
は来材としての石炭酸、クレゾール及びホルマリンの迕

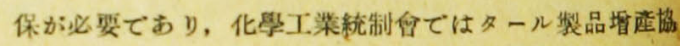
力合に對し石炭配びクレゾールの堵產對策賽施を指令 ナると其にホルマリンについてる供給㙁强に萬全を期し てるるが，これらの各素材は何れる近く供給を堵加し得 る見边て, 從つて合成樹脂の大量㙁㾏が可能視さるるに 至つた

即ち人造石油から生ずる低溫乾溜クンゾールの磪保に よりホルマリンに比し跛行化する傾向にあつたクレゾー

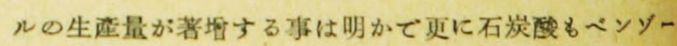

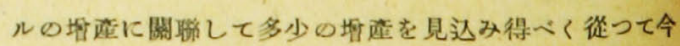
後の合成樹脂生座は可なり坦加を見るであら5

(日經 2 月 4 日)

\section{合成澍脂へ援兵・低溫クレン゙ール分溜點引上げ} 军需省では合成樹脂垉库の烃本要件であ石甚礎原料の磪 保對策として低溫クレン゙ールの描痤に努力して來たが,

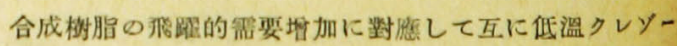

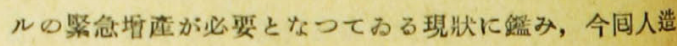
石油工輩の低溫乾勆に於ける低溫クレゾール分溜點を 230 度を 250 度に引上げ垉库を行ふととに決定タール 
製品坦產協力會をして急速に算行させることになり2月 末關係官廳並に化學工業統制會, 合成噺脂統制會社, 人 石の各社を招致して低溫クレゾール挆库合議を開催する 事となつた

分溜點引上げによる生芷量の坦加は低㳑設備によつて

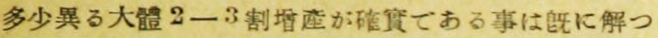
てわた，乙かし分溜點250 度の低溫クレゾールを原料 とした場合に合成樹脂製品の品啠が低下するため現在 までての増産策の決定を見なかつたのであるが, 合成 樹脂統制會社技衡委貝會並に合成樹脂生產合社の技街 陣が㸻意䣲究の結果, 分溜點 250 度の低溫クレソール を合成稫脂原料として工業的に使用し得る事賽を立證 し，てれが分溜點引上げによる增库對策の柤本方針を 決定せしめた原因であつてとこにる我國合成樹脂菠衡 ○優秀性さ窥知出來る(日成絓2月20日)

\section{油脂製品に買取制實施 油脂慜品統制會社ではる}

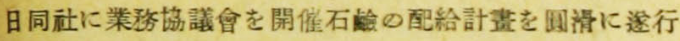

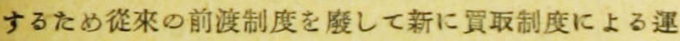
登問题を检討して結果近く筫施する模漛ててれが具體的 問題につルて製造業者と協議亏る事となつた，現在賽施 してるる前洨制度は製造業者の在庫品申請に甚き製品を 確めた上，見返り搒保としてそれに相雷する前洨金を圈 き出荷せしめてるるるのである、日くに生在する製品に 對して前渡したるのと前渡されないるのとが混锚すると 共にてれは單なる金誳操作なるため製品確保上鬼角不完 全性が存するるのてある, この快陷を行ふすのとして 1 月を 3 期 ( 10 日每) と分けて「輸造し得る狀態にある製 品」を製造業者に申告せしめ、これに對して買取做格,

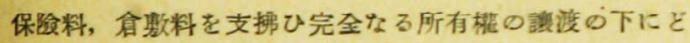
んどん出荷せしめんとするるのてえにより微底的に計畫 配給を實施する(日在䌁 2 月 4 日)

油脂，崟料別に審議委員會 油脂統制會では油脂，

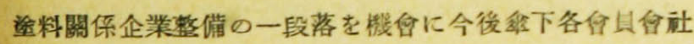
と連絡を祭密にし生座昂揚に遭進することとなり1日理 事會き開慛した結果, 從來の害議委貝合を一段と强化し

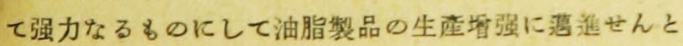

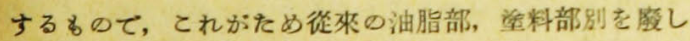
て油脂, 美料別几夫々審議委員會を組織し, 委只を油脂 關係は15名公料關係は10名鉭員するとととなり近く人選 を行ふ，現在の會社關保委具は次の如くである

吉田交熊 (日本油脂) 小池一郎 (地電化) 本瓶㮣興男

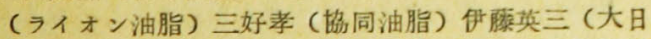
本油脂) 木本一（帝柽）根岸信 (大日本堂料) 小岩管 太郎 (帝國整料) 箕浦多一(日本油脂) 田坂吉二郎(日 本ペイント) 長溇鐵男（軍用石龆工業會）

(日限經2月11日)

譏械油劑工組技術研究㻃 日本機械油劑工組ては
1 日同工組に關東地區主要需要者及び製造業者を招いて

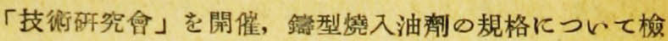
討した(日成經2月11日)

規格改訂を審議 日本機械油劑工組では 3 日午後 1 時束京丸/內永樂クラブに「技衔委只會」を開倠, 商 工省告示 335 號「切削油劑, 洗條油劑」685 號「その他 の機械油版」规格の改訂問䞨について審議する。

(日産綛2月11日)

\section{肺炎や脚氣の踭防薬・日本化成, 鐵興社で工業}

化 最近スルフォン剂, ヴイタミン劑等の醫樂品は著し

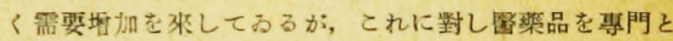
しない日本化成，鐡舆社等が䁷富な甚磷藥品と有機合成 化學の技衡を活用して工業化に乘出したてとは極めて洼

\section{目される}

郎ち日本化成では同社研究室によつて日本ては最初の スルフアチアソールの合成に成功して戡に市眅を開始し た,との新スルフォン劑は肺炎に特効がある, 又鐵興社 ては昨年ヴイタミン B，の合成に成功し非常に复雜な工 程により工業的生產を開始してるるが，その製品は從來 の抽出裂品に比して非常に純粹なるのが得られ, 脚氣の 瑔防, 疲勞国復等に役立つ, 右の外日本染料は子會社日 本染料暂品によりスルフォン劑を始め各種合成藥の開拓 に努めつつある(日齐經 2 月 2 日)

寫道感光材料統制臨時總會 日本倪眞感光材料統 制畣社臨時䍃合は10日午後 1 時から, 東京都丸の內工業 俱樂部にて閉催, 次の件を附識する

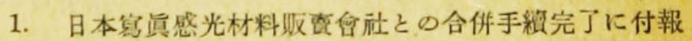
告の件

2. 定款變页の件

（イ）炤和18年12月28日の䀦時株主䍃留に物いでし たる定款第 5 條改正の件を左記の通り修正す 第 1 號議案の合併と同時に定歀第 5 佟を左の通り變 更方

第 5 像 本合社の褧本は金 219 萬国 と定め之を 43800 株 に分ち 1 株の金額を 50 [圆全額拂込浑みとす，前記總會

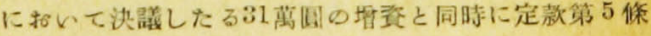
を次の通り變页す

第 5 倈 本自社の凒本は金 250 萬组と定め之を 5 萬株に

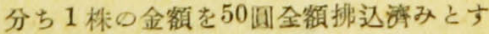

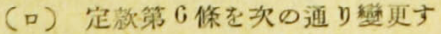

第 6 你 本会社の株式は記名式とし株券の租類は 10 株 券, 50 秼券及び 100 株券の劉程とす

(八) 定款第17保を次の通り變更す

第17你 株主總會の決議は出席株主の辇決模の牛数以上 を以つて之を決す, 可否同數なるとをは烀長これを決 す但し之により議長の株主としての議決權の行使を好 げナ゙ 
(二) 定㪍第 18 條を次の通り愁页す

第18集 本會社に左の役員を置く, 取締役 15 名以內, 監 查役 3 名以內

(ホ) 第19條を次の通り變更す

第19條 取締役の互選に依 $り$ 社長 1 名, 副社長 1 名を定 め常㢦取締役 3 名を定むることを得, 監查役の互邀に 依り常任監查役を 1 名定むることる得, 本會能を代表 すいき取締役は社長祸上び副社長とす

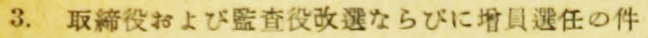

4. 役員報獎額决定の件

なほ站長には現感光材料統制會社斻長平野久保氏, 副社

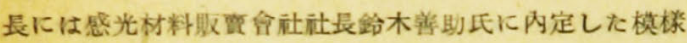

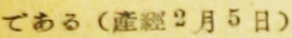

三井物産化萃部て農藥研究所を新設 三井物差て は時局の而大性にかんがみ各部に握にてそれぞれ新計福 を考究中であるが、その中に敊て化學部では戰時下食

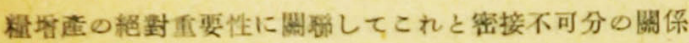

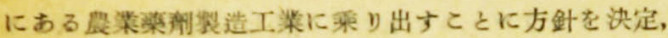

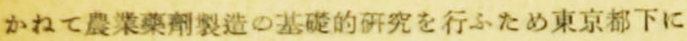

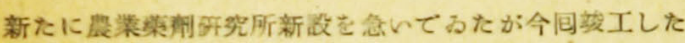

セル統制雷社創立 セルロイド生地, 属兩統制合社 と合併し統制合社命に悲く日本七ルロイド統制合社の刢

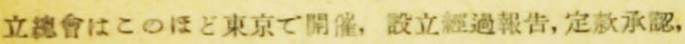

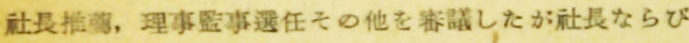
に役貝は次のどとく決定を見た

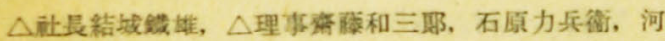

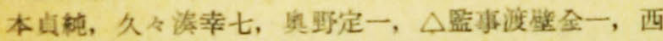
出常盛, 浅田

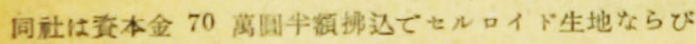

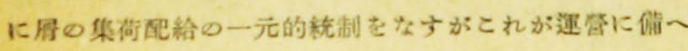

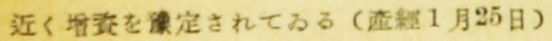

日空同化埧生座費任者選任 日室では22日東京に

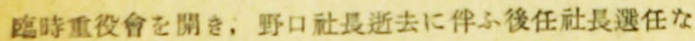
らびに合最制の新設に上り次の役只を互選，それぞれ年 格就任した（括弧队前職）

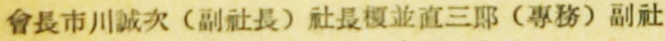

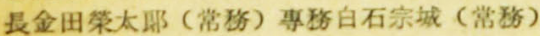

また雷日の重役會で故野口氏が社長でった左記伤系會 社の新就辰を決定した（括张內前䣹）

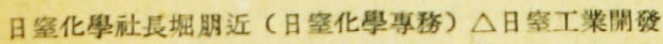

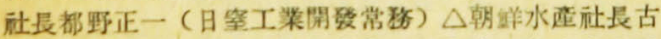

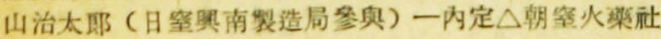
長宮本正治 (朝空火新常䅂)

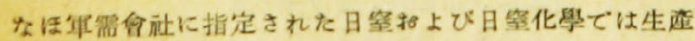
责任者としてそれぞれ椱並，堀の新社晨を互退した (每日 1 月24日)

三菱化成に決る・日本化成, 旭硝子の合併新社
日本化成と担硝子は愈々合件して 4 月 1 日から三落化成 の新名稱下に發足する事となつたが，新沶は單なる貴本 統合のみに涩足せず稓極的經營に進む事となつた, 即ち 新社が成立したのはア法ソーダ工業の整備に甚くるのて はあるが三菱としては之を機會として化學工業部門に對

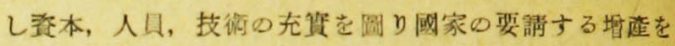
贯現せしめる事となつた，主要坦部部門は下記の通り

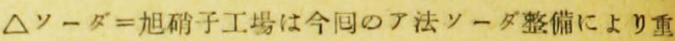
點工場となつたので，原祭の配給は從來上りも向上し

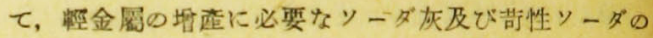
垁產に注力する事となつた

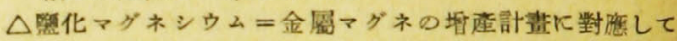
明年度は更に㙁应を行ふ

$\triangle$ 硝酸=日本化成工場は确酸の生库者としては日空，東 洋高原等に比し比䧶的新しい生看者であるが, 獨特の 技街に上つて坦应を四りつつある

$\triangle$ 有機ガラス＝之は最初旭硝子が工業的生座に成功し日 本化成としては最近閒始したるのであるが、今後も兩 社が一體となつて各工䭪に於る城座を圆る事となつた なほ兩社が合併した絬果化學工業其䃈維品たるソーダ, アンモニア硫酸及びタール製品を有効に使用し得るので 今後口綡合的運營は極めて注目される(日座1月31日)

山本硫酸統制理事東京本社常勤 䂠酸緒制會社理 本に就任した山本宣粑氏は今间束京本刑に常㸚する事と なつた(日看經 1 月31日)

オイルシートパ,キングに近く因 日本人造皮 革工稀はオイルシートハッキング筡造一本に裂造方針を

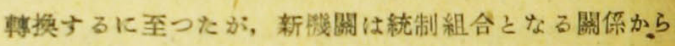
現在協定洒格に化つてふるオイルンートパッキンク゚の中

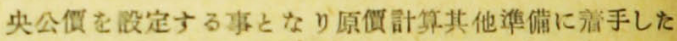

(日座緑2月11日)

樟腦製造目標達成人 專雷局では 1 月下旬各地方

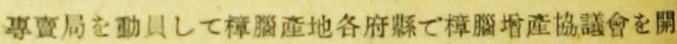

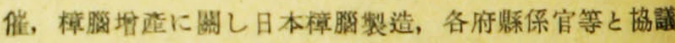
したが，この繥果に基き日本样腦製造では各精油所を總

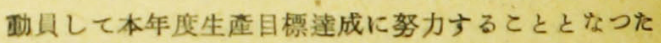

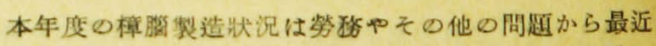

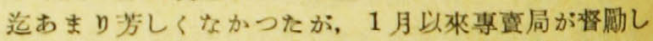

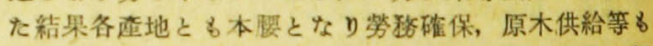
樟腦がセルロイド原料として, 樟腦油が鑹物㙕産に無

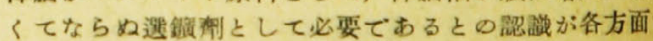

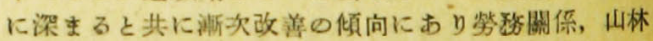
關保保官む糟極的協力を情ま如情势となつて來えのて 今後は業者侧でどらしてる生有目標を達成しなければ ならぬと意氣込んで居り，18年度前牛の不振を後牛で 损国する方針で努力してるる なほ19年度はこの調子で行けば18年度に比し著しく增產 させることが出來る䂺定である(日在經2月11日) 
なり。全身に亘り水泡を生す。作業後身體を洗ひ たるも倘, 水泡を生じたり。約 1 万月休養す。

4. 火傷と同樣の處置を行へば良い。

5. 作業後直ちに水又は湯にて洗落す。始めよ り拭ふ事は却つて被害を大にする。上記の如くし て何犯さる者は作業に從事する事不可能なる者に して，斯る者は極めて稀なり。

6. ナフトキノーンは刺战性臭氣を有し落涙せ しさ。肥滿性の皮腐の薄い人が多く䓠り，一般に は差程恐れるに足らない。

\section{2. タールに依る中毒}

1. 男 職工 34 蔵

2. 7 月下旬

3. ピ, 于乾溜に際して壮發生するタール蒸氣

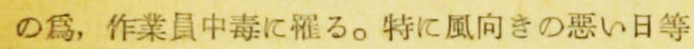
は風下は谌しい, 皮有露出部に對しては口, 眼に 痛みを感し後顛全體に及心゙。日光の下にては刺皒 甚しく，時の經過に從ひ烈しくなる，日莞に於て は比䡛的痛みは弱いが，日光を受ける每に痛みを 感す, 藤蔽部に對しては顔の如き痛みは感せとかが, 數日後辉みを來し赤くなり日數の經るに從ひ，體
特に胸背等の毛穴に發疹を來した。俗にタール疥 㾕と云ふ。顏面の痛み洗面時特に甚だしけれと゚ 次第に痛みは薄れて來る。體の棒みは㴬次激しく なるがタール蒸军に觸れねば薄れて來る。これ は一度かかれば當分かからない㥞である。

4. 治療方法は未だ㖆究中なるが，作業直後の 皮膚刺㦸に對しては亞鉛華リメント又は亞鉛華オ レフ油を症布する。發疹病狀を是するものには砷 酸軟㲤を使用すると効果がある。

5. 顏面潒防には活性炭素充鎮のカンスター付 防毒面を用ひる。又ピ。チ缘防白粉を厚く塗布す

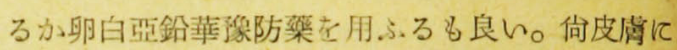
附着したるるのは出來るだけ早く石鹼で洗ひ落し 亞鉛華淙粉を撒布する。單なる防塺眼鏡て依り目 の刺敦は豫防し得らる。

又㗐，衣服は常に涯潔を保ち作業後頝面にオキ

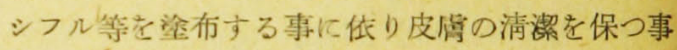
が出來る。

6.（刺战性タールの蒸氣成分)監基性として高 級ビリチン血基, 酸性としては高級フェフール等 である。生理的作用亡しては酸性が最多烈しい。

\section{粟思 工場用試藥の計畫配給 情勢重齐協加盟團體で}

武奥統制合社ては愈之昭和 19 年第 14 年期か 5 計盖配

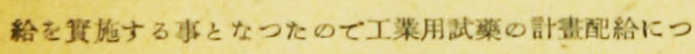

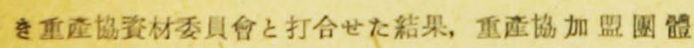
(統制會等)の各工場に数する陚橧の配給については左 の措置を满ずる事となつた

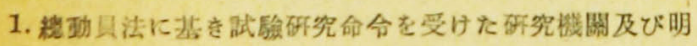
確に【場と區別し得る獨立の研究所に缽する試樂は科

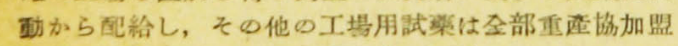
国體 (統制分等) 加 万工場單位に配給する

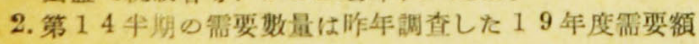

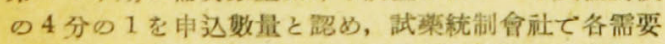

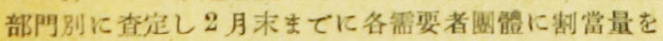

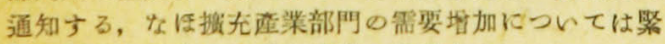
急需要として申請を受け別途に處理する

3. 第 14 牛期の配給に限 $\boldsymbol{\eta}$ 就菜統制會社で需要工場に對 する配給所を指定する

4. 航空部門に對する配給は莗需省威保者間で速絡の上別 途に考虑する

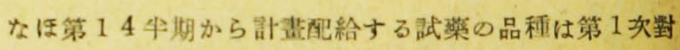
象 360 種中製品规格及び公僄が既に決定した 50 種て 规格，公倾が決定すれば更に迫加する方針だが 50 種は 左の如し

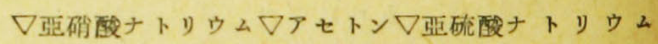
(結品) $\nabla$ 亞硫酸ナトリウム (無水) $\nabla$ マンモニア水

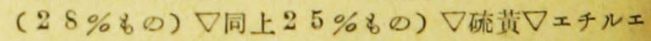

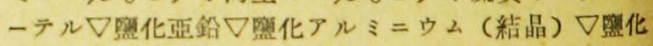

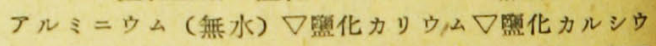

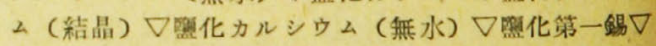

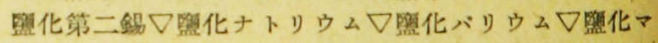
グネシウム、照莱酸カリウム、過マンガン酸カリウム

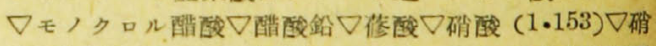
酸 (1.38) 㗂酸 $(1.42) \nabla$ 砣酸カリウム硝酸银 $\nabla$ 硝酸ナトリウム 湠睃カリウム $\nabla$ 炭酸ナトりウム ム $\nabla$ 重クロム份ナトリウム

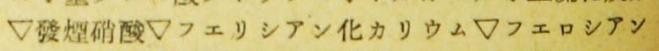

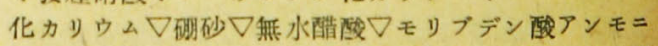
ウム $\nabla$ 硫化ナトりウム $\nabla$ 硫酸柃 (結品) $\nabla$ 無水硫酸铜 $\nabla$ 硫酸ナトリウム(結唱) $\triangle$ 同上 (無水) $\nabla$ (日曐經 1月21日) 